\title{
PELINDUNGAN HUKUM TERHADAP MEREK TERKENAL (WELL-KNOWN MARK) ATAS PASSING OFF PADA DIGITAL PLATFORM MARKETPLACE
}

\author{
Karenina Aulia Puti C., Fakultas Hukum Universitas Padjadjaran, e-mail: \\ kareninaulia@gmail.com \\ Ranti Fauza Mayana, Fakultas Hukum Universitas Padjadjaran, e-mail: \\ ranti_fauza@yahoo.com
}

Tasya Safiranita Ramli, Fakultas Hukum Universitas Padjadjaran, e-mail: tasya_safiranita@yahoo.com

doi: https://doi.org/10.24843/KS.2020.v08.i11.p03

\begin{abstract}
ABSTRAK
Adanya fenomena disrupsi digital menyebabkan praktik passing off tidak hanya ditemukan dalam pasar konvensional namun juga dalam perdagangan elektronik, yaitu pada bentuk digital platform marketplace. Penelitian ini bertujuan untuk, pertama, mendapatkan pemahaman mengenai pelindungan hukum merek terkenal terhadap passing off atas merek terkenal pada digital platform marketplace di Indonesia. Kedua, mendapatkan pemahaman mengenai tindakan hukum yang dapat dilakukan pemilik merek terkenal terhadap pedagang dan penyedia digital platform marketplace terhadap passing off pada digital platform marketplace. Penelitian ini berbentuk deskriptif-analitis yang menggunakan pendekatan yuridis-normatif serta menganalisis data dengan metode normatif-kualitatif. Teknik pengumpulan data yang dilakukan yaitu studi kepustakaan dengan mengakaji data sekunder. Hasil penelitian menunjukkan bahwa berdasarkan Undang-Undang No. 20 Tahun 2016 tentang MIG dan Undang-Undang-Undang No. 19 Tahun 2016 tentang Perubahan Atas Undang-Undang No. 11 Tahun 2008 tentang ITE, pemilik merek terkenal memiliki pelindungan hukum atas praktik passing off yang dilakukan dalam digital platform marketplace dan dapat melakukan tindakan-tindakan seperti mengajukan gugatan ganti rugi dengan memohon ganti rugi baik materil maupun immateril serta dapat mengajukan gugatan kepada Pengadilan Niaga sebagai bentuk ultimatum remedium. Namun untuk mendapatkan pelindungan lebih komprehensif pemilik merek terkenal haruslah mendaftarkan mereknya terlebih dahulu dan juga sebelum mengajukan gugatan dapat melakukan pengaduan kepada masing-masing digital platform marketplace.
\end{abstract}

Kata Kunci: Merek Terkenal, Passing Off, Digital Platform Marketplace.

\begin{abstract}
The phenomenon of digital disruption causes the practice of passing off not only found in conventional markets but also in electronic commerce, which is a digital platform marketplace. This research aims to, first gain an understanding of the legal protection of well-known marks against passing off on the digital platform marketplace in Indonesia and second, gains an understanding of legal actions that can be done by well-known marks owners towards traders and digital platform marketplace providers towards passing off on the digital platform marketplace. This research is in the form of descriptive-analytical using a juridicalnormative approach and analyzing data with normative-qualitative methods. The data collection technique used is library research by assessing secondary data. The results showed that based on Law No. 20 of 2016 on Marks and GI and Law No. 19 of 2016 concerning Amendments to Law No. 11 of 2008 on EIT, it said that the owner of well-known marks has legal protection for the practice of passing off carried out in the digital platform marketplace and can take actions such as filing a claim for compensation by requesting compensation both material and immaterial and can file a lawsuit to the Commercial Court as a form of
\end{abstract}


ultimatum remedium. In order to have full protection, the owner of the well-known mark must register the trademark first and also before filing a lawsuit can make a complaint to each digital platform marketplace.

Keywords: Well-known Marks, Passing Off, Digital Platform Marketplace.

\section{Pendahuluan}

\subsection{Latar Belakang Masalah}

Perubahan yang terjadi saat ini didukung oleh perkembangan teknologi informasi dan komunikasi yang cepat sehingga mengubah perilaku masyarakat dan peradaban manusia secara global ${ }^{1}$. Salah satu perubahan yang diakibatkan oleh perkembangan teknologi informasi adalah perilaku manusia dalam mewujudkan hasil kekayaan intelektualnya. Saat ini kita dapat melihat kekayaan intelektual secara digital melalui platform online secara mudah.

Kekayaan intelektual didasarkan pada pemikiran manusia yang memerlukan pengorbanan seperti tenaga, waktu, dan biaya. Pengorbanan yang telah dikeluarkan tersebut menghasilkan suatu karya yang memiliki manfaat dan dapat menghasilkan nilai ekonomi. ${ }^{2}$ Oleh karena itu, perlunya diberi penghargaan atas hasil karya itu berupa pelindungan hukum kekayaan intelektual. Pada umumnya hukum kekayaan intelektual merupakan pelindungan atas penerapan ide-ide manusia yang diwujudkan secara nyata.

Salah satu kekayaan intelektual yang memiliki nilai ekonomi tinggi adalah merek. Merek merupakan kekayaan intelektual yang selalu digunakan pelaku usaha dalam kegiatan perdagangannya dalam bentuk logo, gambar, atau tulisan. Merek digunakan untuk mengidentifikasi barang dan jasa yang diproduksi atau distribusi oleh pelaku usaha, sehingga pelaku usaha selalu mendaftarkan mereknya sehingga memberikan hak kepada pelaku usaha tesebut untuk menggunakan mereknya secara eksklusif. Pemilik merek terdaftar juga memiliki hak untuk mencegah pihak lain menggunakan mereknya tanpa izin. ${ }^{3}$

Tindakan Indonesia dalam memberikan pelindungan terhadap merek dengan adanya undang-undang khusus untuk mengatur merek yaitu Undang-Undang Nomor 20 tahun 2016 tentang Merek dan Indikasi Geografis yang selanjutnya disebut UU MIG. Namun, dalam undang-undang ini tidak mengatur tingkatan merek berdasarkan reputasi tetapi pada umumnya para pakar membedakan tingkat derajat berdasarkan kemasyhuran yang dimiliki oleh berbagai merek, tingkatan tersebut terbagi menjadi tiga, yaitu merek biasa (normal mark), merek terkenal (well-known mark), dan merek termashyur (famous mark). ${ }^{4}$

Merek terkenal merupakan merek yang diketahui secara luas oleh sektor-sektor relevan di dalam masyarakat, dalam hal ini promosi merupakan sarana paling efektif untuk membangun reputasi suatu merek. ${ }^{5}$ Merek terkenal memiliki ciri utama yang salah satunya bahwa reputasi merek tidak terbatas pada produk tertentu atau dilihat kebanyakan jenis barang yang tidak berhubungan dengan merek terkenal telah

1 Ramli, Ahmad M. Cyber Law dan Haki, (Bandung: Refika Aditama, 2018), 1.

2 Alfons, Maria. "Implementasi Hak Kekayaan Intelektual dalam Perspektif Negara Hukum". Jurnal Legislasi Indonesia, Volume 14, Nomor 3, (September 2017): 304.

3 Lindsey, Tim (et.al.), Hak Kekayaan Intelektual. (Bandung: Alumni, 2013), 8.

4 Harahap, Yahya. Tinjauan Merek Secara Umum dan Hukum Merek di Indonesia Berdasarkan Undang-Undang No 19 Tahun 1992, (Jakarta: Citra Aditya Bakti,1996), 80.

5 Jened, Rahmi. Hukum Merek dalam Era Globalisasi \& Integrasi Ekonomi, (Jakarta:Kencana. 2015), 241. 
dieksploitasi untuk jenis barang dan jasa yang berbeda. Ciri lain dari merek terkenal yaitu pelindungan diberikan dalam hubungan pemakaian secara umum dan tidak hanya pada barang yang berhubungan dengan jenis barang saat pendaftaran merek. ${ }^{6}$

Meskipun dalam UU MIG tidak mengklasifikasikan merek berdasarkan tingkat kemasyhuran, tetapi merek terkenal diakui dalam Pasal 21 ayat (1) huruf b yang membicarakan alasan penolakan permohonan merek jika mempunyai persamaan pada pokoknya atau keseluruhan dengan merek terkenal. Oleh karena itu diperlukannya penafsiran atas UU MIG terhadap adanya merek terkenal.

Lebih lanjut, pada kegiatan perdagangan, pelaku usaha sering kali tidak beritikad baik salah satunya dengan melakukan pemboncengan reputasi merek terkenal (wellknown mark) untuk memperdagangkan produknya yang sebenarnya bukan bagian dari merek terkenal tersebut. Hal tersebut dilakukan guna meraih keuntungan sebesarbesarnya tanpa mengeluarkan usaha yang besar karena tidak perlu membangun reputasi suatu merek baru. Kegiatan pemboncengan reputasi suatu merek disebut sebagai Passing off. Passing off merupakan pranata yang sering ditemui di sistem common law sebagai tindakan pemboncengan reputasi suatu merek untuk mendapatkan keuntungan bagi pihak yang melakukan tindakan tersebut. ${ }^{7}$ Tindakan ini dapat terjadi dengan membonceng melalui cara meniru dan memirip-miripkan kepada merek pihak lain yang telah memiliki reputasi baik ${ }^{8}$

Passing off ini selain dapat disebut pelanggaran merek tetapi juga dapat dikenakan gugatan atas persaingan usaha tidak sehat. Hal ini dikarenakan pemboncengan reputasi atas suatu merek terkenal yang dilakukan oleh pelaku usaha yang belum memiliki reputasi sebesar merek terkenal berusaha meraih keuntungan dari pemanfaatan reputasi tersebut sehingga dapat merugikan pemilik merek terkenal terdaftar dan menyesatkan masyarakat. Selain itu praktik passing off juga kerap kali ditemukan dikarenakan saat ini pendaftaran merek sudah dilakukan secara online dan belum efektifnya parameter pengukur merek yang dimohonkan dengan merek yang sudah ada dan terkenal yang mengakibatkan mudahnya penerimaan atas permohonan pendaftaran merek yang menimbulkan kesamaan pada merek yang sudah ada yang menyebabkan kesamaan-kesamaan yang membingungkan masyarakat. Oleh karena itu perlu adanya penegakan hukum untuk memberikan sanksi kepada pelaku passing off tersebut.

Adanya fenomena disrupsi digital merupakan perubahan yang fundamental dengan mengacak-acak serta melibas pola tatanan lama untuk menciptakan tatanan baru9 ${ }^{9}$, yang menyebabkan passing off tidak hanya ditemukan dalam pasar konvensional tetapi juga sering ditemukan dalam perdagangan elektronik. Salah satu situs perdagangan elektronik yang sering digunakan masyarakat yaitu pada jenis consumerto-consumer atau yang biasa disebut digital platform marketplace. Digital platform marketplace atau yang biasa disebut e-marketplace, pembeli dan penjual dapat mengkomunikasikan informasi tentang harga, produk yang dijual, serta mampu

6 Lindsey, Tim. Op.cit. 150.

7 Sunny, Dio Shafreeza. "Tanggung gugat produsen pemilik produk yang melakukan pemboncengan reputasi", (Skripsi Universitas Airlangga, Surabaya), 19.

8 Ahyani, Sri. "Perlindungan Hukum Terhadap Merek atas Action for Passing Off". Jurnal Wawasan Hukum, Vol 27 No, 02, (2012): 544.

9 Ramli, Ahmad M. Hak Cipta, Disrupsi Digital Ekonomi Kreatif, (Bandung: Alumni. 2018), 88. 
menyelesaikan transaksi jual beli secara elektronik melalui digital platform marketplace tersebut. ${ }^{10}$

Praktik passing off yang dilakukan dalam situs marketplace menyebabkan penegakan hukumnya juga perlu memperhatikan dari sisi hukum teknologi informasi dan dapat dikatan sebagai praktik dalam kegiatan siber. Regulasi hukum siber menjadi bagian penting dalam sistem hukum positif secara keseluruhan. Indonesia memiliki hukum positif yang mengatur kegiatan siber yaitu Undang-Undang No. 11 tahun 2008 tentang Informasi dan Transaksi Elektronik yang kemudian diperbaharui ke dalam Undang-Undang No.19 tahun 2016. Namun, undang-undang tersebut tidak mengatur secara tegas mengenai passing off atas merek terkenal dalam digital platform marketplace.

Praktik passing off yang sering ditemukan dalam digital platform marketplace dilakukan oleh para pedagang (merchant) sebagai siasat untuk menaikkan promosi produknya tanpa perlu mengeluarkan biaya untuk memasang iklan yang dikenakan tarif tertentu dari digital platform marketplace bersangkutan. Hal ini dilakukan dengan mencantumkan merek yang sama secara keseluruhan dengan merek terkenal pada laman informasi produk yang dijual oleh merchant. Salah satu praktik yang ditemukan yaitu dijualnya produk lokal berupa jaket wanita dengan merek yang masih asing di masyarakat yaitu "HEYLOOK", namun dalam judul informasi terkait produk ia mencantumkan merek terkenal yang juga bergerak di bidang pakaian dan sudah dikenal luas oleh masyarakat yaitu "Supreme" dan "Vans"11. Hal ini tentu menguntungkan pedagang (merchant) dikarenakan siasat yang ia lakukan untuk promosi berhasil menaikkan jumlah peminat dengan cara menarik masyarakat pembeli potensial produk merek terkenal tersebut untuk melihat produk yang dijual oleh pedagang (merchant). Sehingga hal ini tentu merugikan pemilik merek terkenal dan menimbulkan kebingungan bagi masyarakat sebagai konsumen digital platform marketplace.

Namun dikarenakan praktik passing off merupakan praktik yang dilakukan oleh pedagang mengakibatkan masyarakat sebagai konsumen digital platform marketplace disesatkan oleh informasi dan juga dapat merugikan secara materil dan immateril bagi pemegang merek terkenal yang terdaftar sehingga pedagang dapat dikenakan sanksisanksi.

\subsection{Rumusan Masalah}

Bertolak dari latar belakang yang telah dipaparkan diatas, maka permasalahan yang akan dibahas dalam penelitian sebagai berikut:

1. Bagaimana pelindungan hukum merek terkenal atas Passing off pada digital platform marketplace berdasarkan Undang-Undang No. 20 tahun 2016 tentang Merek dan Indikasi Geografis dan Undang-Undang No. 19 tahun 2016 tentang Perubahan Atas Undang-Undang No. 11 tahun 2008 tentang Informasi dan Transaksi Elektronik?

2. Bagaimana tindakan hukum yang dapat ditempuh oleh pemilik merek terkenal terhadap pedagang (merchant) yang melakukan passing off pada digital platform marketplace berdasarkan Undang-Undang No. 20 tahun 2016 tentang Merek dan Indikasi Geografis dan Undang-Undang No. 19 tahun 2016

10 Marco, Robert dan Ningrum, Bernadheta Tyas Puspa, "Analisis Sistem Informasi Emarketplace Pada Usaha Kecil Menengah (UKM) Kerajinan Bambu Dusun Brajan", Jurnal Ilmiah DASI, Volume 18. Nomor 2, (Juli 2017): Hlm 49

11 Hasil penelusuran pada salah satu digital platform marketplace yaitu Shopee.com, pada tanggal 16 Mei 2019. 
tentang Perubahan Atas Undang-Undang No. 11 tahun 2008 tentang Informasi dan Transaksi Elektronik?

\subsection{Tujuan Penelitian}

Tujuan dari tulisan ini adalah untuk mendapatkan pemahaman mengenai pelindungan hukum merek terkenal terhadap passing off atas merek terkenal pada digital platform marketplace di Indonesia dan untuk menganalisis mengenai tindakan hukum yang dapat dilakukan pemilik merek terkenal terhadap pedagang dan penyedia digital platform marketplace terhadap passing off pada digital platform marketplace di Indonesia

\section{Metode Penelitian}

Penelitian yang digunakan dalam penulisan hukum ini dengan pendekatan yuridis normatif yaitu penelitian dengan bahan pustaka yang mencakup bahan hukum primer seperti peraturan perundang-undangan yang berlaku serta bahan hukum sekunder, dan bahan hukum tersier sebagai pendukung. ${ }^{12}$ Lebih lanjut, spesifikasi penelitian ini adalah deskriptif analitis yang bertujuan untuk memperoleh suatu uraian atau gambaran umum yang menyeluruh dan sistematis, serta menguraikan keadaan ataupun fakta yang ada. Metode yang digunakan dalam analisis data adalah normatif kualitatif. Normatif yaitu didasarkan pada peraturan-peraturan hukum yang ada sebagai norma hukum positif, sedangkan kualitatif dalam menganalisis data yaitu bertitik tolak pada usaha penemuan asas dan informasi.

\section{Hasil Dan Pembahasan}

\subsection{Pengaturan dan Pelindungan Hukum terhadap Merek Terkenal atas Praktik} Passing Off dalam Digital Platform Marketplace

Transaksi elektronik merupakan perbuatan hukum yang dilakukan melalui komputer, jaringan komputer, atau media elektronik lainnya ${ }^{13}$. Transaksi elektronik yang saat ini menjadi transaksi yang selalu digunakan sehari-hari didukung dengan adanya internet. Adanya internet mendukung pertumbuhan sistem informasi dan teknologi yang telah digunakan pada banyak sektor kehidupan, salah satunya sektor perdagangan ${ }^{14}$.

Perdagangan dalam sistem elektronik merupakan proses transaksi jual beli yang dilakukan oleh seseorang terhadap seseorang lainnya dengan media internet dalam waktu yang yang tidak terbatas dan dimanapun tanpa perlu face to face antara para pihak yang cukup mengandalkan rasa kepercayaan antara para pihak ${ }^{15}$. Perdagangan dalam sistem elektronik ini menggunakan prinsip-prinsip perjanjian yang sama dengan perdagangan konvensional seperti Pasal 1233 KUHPerdata yang menyatakan "tiap-tiap perjanjian dilahirkan baik karena persetujuan maupun undang-undang" kemudian dilanjutkan Pasal 1320 KUHPerdata yaitu syarat sah perjanjian yang terdiri dari sepakat mereka yang mengikatkan diri, kecakapan untuk membuat suatu perikatan, suatu hal

12 Soekanto, Soerjono, Pengantar Penelitian Hukum, (Jakarta: UI Press, 1986), 52.

13 Budhijanto, Danrivanto. Hukum Telekomunikasi, Penyiaran \& Teknologi Informasi. (Bandung: Refika Aditama, 2010), 138.

14 Ibid, 1.

15 Setyawati, Desy Ary dan M, Dahlan dan Rasyid, Nur. Perlindungan Bagi Hak Konsumen dan Tanggung Jawab Pelaku Usaha Dalam Perjanjian Transaksi Elektronik. Syiah Kuala Law Journal. Vol 1 No. 3.(2017): 35. 
tertentu, dan suatu kausa yang halal ${ }^{16}$. Namun penerapan prinsip-prinsip tersebut tentunya berbeda dengan transaksi konvensional karena pada perdagangan elektronik diperantarai oleh sistem elektronik.

Perlunya kepastian hukum dalam perdagangan yang dilakukan dalam cyberspace tersebut maka harus memperhatikan dari aspek cyber law. Oleh karena itu, hukum sebagai sarana pembangunan melahirkan Undang-Undang No. 11 Tahun 2008 tentang Informasi dan Transaksi Elektronik yang kemudian dilakukan perubahan pada Undang-Undang No. 19 Tahun 2016 untuk mengarahkan masyarakat menjaga ketertiban dalam kegiatan-kegiatan pada cyberspace terutama transaksi elektronik.

Perdagangan elektronik atau biasa disebut e-commerce memiliki berbagai jenis, yang salah satunya adalah digital platform marketplace dimana konsumen melakukan transaksi langsung ke konsumen lainnya di dalam situs platform marketplace. Transaksi dalam digital platform marketplace berkaitan erat dengan aspek hukum kekayaan intelektual. Hal ini tertuang dalam Pasal 25 UU ITE sebagai jembatan memberikan pelindungan terhadap segala kekayaan intelektual dalam sistem informasi dengan memperhatikan peraturan kekayaan intelektual terkait.

Pada jenis e-commerce ini banyak ditemukannya pelanggaran terkait kekayaan intelektual salah satunya merek yang dilakukan oleh pedagang (merchant). Merek sebagai kekayaan intelektual yang memiliki nilai ekonomis yang tinggi menyebabkan sering disalahgunakan oleh pihak yang tidak bertanggung jawab guna meraih keuntungan.

Praktik passing off atau praktik pemboncengan reputasi merupakan pelanggaran merek yang banyak ditemukan dalam berbagai situs platform marketplace. Praktik ini merupakan pelanggaran terhadap merek sebagai hak eksklusif yang dimiliki pemilik terdaftar yang dilakukan oleh pihak yang tidak berhak memanfaatkan merek tersebut untuk kegiatan usahanya guna meraih keuntungan yang besar tanpa itikad baik. Pada umumnya praktik passing off ini dilakukan terhadap merek yang telah memiliki reputasi dan tergolong merek terkenal (well-known mark). Dalam negara common law, passing off dikategorikan perbuatan curang dalam bisnis, Mollengraf menegaskan bahwa persaingan yang bertujuan untuk mengelabui masyarakat dan merugikan pesaingnya dan untuk menarik pelanggan atau memperbesar peredaran barang-barangnya, merupakan persaingan berbentuk penggunaan upaya yang bertentangan dengan kesusilaan dan kejujuran dalam pergaulan hukum ${ }^{17}$. Perbuatan pemboncengan reputasi ini tergolong perbuatan persaingan curang yang memiliki sifat-sifat berikut: ${ }^{18}$

1. Menipu dalam penjualan berkenaan dengan merek dan barang;

2. Penggelapan (misappropriation) nilai-nilai yang sulit diraba;

3. Bersifat jahat (malicious)

Praktik passing off dalam digital platform marketplace ini perlu dikenakan tindakan hukum, dikarenakan praktik ini dapat menyebabkan kerugian bagi pemilik merek serta menimbulkan kebingungan bagi masyarakat sebagai konsumen. Praktik pemboncengan reputasi dalam situs marketplace ini merupakan resiko merek sebagai salah satu

16 Sanjoto, Liany Dewi. Perlindungan Hukum Bagi Konsumen Pemakai Jasa Elektronik dalam Transaksi Melalui Marketplace. Jurnal Ilmiah Dunia Hukum.Vol.3 No. 2. (2019): 100.

17 Kurniasih, Dwi Agustine. Perlindungan Hukum Pemilik Merek Terdaftar Dari Perbuatan Passing Off (Pemboncengan Reputasi). Jurnal Media HKI. Vol. V. No. 6. (2008): 7.

18 Quintina, Aurora et.al. Pemboncengan Reputasi (Passing Off) Terhadap Prmilik Merek Terdaftar Di Indonesia Ditinjau Dari Segi Perlindungan Hukum. Jurnal Mercatoria. Volume 2 Nomor 1. (2009): 15. 
kekayaan intelektual yang sejalan dengan risk theory yaitu pemilik merek akan menghadapi risiko pelanggaran hak akibat adanya penggunaan merek secara melawan hukum. ${ }^{19}$

Praktik passing off dalam digital platform marketplace dilakukan dengan melakukan pemasangan iklan yang mencantumkan merek terkenal, sehingga diperlukan pencabutan iklan yang mengandung praktik passing off. Pada praktiknya, proses pencabutan konten iklan yang melanggar merupakan wewenang idEA sebagai asosiasi e-commerce. Namun proses pencabutan ini memakan proses yang lama diakibatkan adanya pengalihan pengaduan dari Kominfo kepada idEA. Walaupun sudah terdapat peraturan yang melarang penjualan barang palsu yang melanggar merek dan kekayaan intelektual tetapi masih banyak ratusan juta konten iklan dalam e-commerce ditemukan bermasalah sehingga mengalami kesulitan dalam pencabutan konten. ${ }^{20}$

Perkembangan teknologi yang semakin maju menyebabkan resiko yang dihadapi pemilik merek tidak hanya terjadi di dunia nyata dalam bentuk pelanggaran merek konvensional seperti persamaan atau penggunaan merek untuk produk palsu ${ }^{21}$, namun resiko dialami oleh pemilik merek dalam dunia maya yaitu pada digital platform marketplace dengan bentuk praktik passing off. Pelanggaran merek yang ditemukan dalam digital platform marketplace ini perlulah keadilan bagi pemilik merek meskipun pelanggaran merek yang dilakukan oleh pedagang (merchant) belum ada pengaturannya dalam Undang-Undang No. 20 Tahun 2016 tentang Merek dan Indikasi Geografis, selanjutnya disebut UU MIG.

Meskipun pemilik merek belum mendapat pelindungan atas praktik pemboncengan reputasi yang dilakukan dalam marketplace, tetapi dapat dikenakan pelindungan melalui penafsiran UU MIG serta UU ITE. Terdapat perbedaan penafsiran antara doktrin passing off pada negara common law dan dalam UU MIG, yaitu jika pada negara common law merupakan perlindungan pada merek yang belum terdaftar sedangkan dalam UU MIG memberikan perlindungan terhadap merek yang telah didaftarkan.

Hal tersebut dinyatakan dalam Pasal 1 ayat (5) UU MIG yang menyatakan bahwa Hak atas Merek adalah hak eksklusif yang diberikan oleh negara kepada pemilik Merek yang terdaftar untuk jangka waktu tertentu dengan menggunakan sendiri Merek tersebut atau memberikan izin kepada pihak lain untuk menggunakannya. Dilanjutkan oleh Pasal 3 UU MIG yang menyatakan bahwa hak atas merek diperoleh setelah Merek tersebut terdaftar. Maka berdasarkan pernyataan tersebut suatu merek akan mendapatkan pelindungan dan pemilik merek mendapat hak ekslusif suatu merek apabila telah melalui serangkaian proses pendaftaran yaitu permohonan pendaftaran, pemeriksaan formalitas, proses pengumuman, dan proses pemeriksaan substantif serta telah mendapatkan persetujuan Menteri untuk diterbitkan sertifikat sehingga terdaftarnya merek barulah merek tersebut mendapatkan pelindungan penuh sesuai dengan UU MIG.

Passing off atau pendomplengan merek terkenal yang dilakukan oleh pedagang (merchant) dalam digital platform marketplace dilakukan dengan cara mencantumkan

19 Muhammad Amirulloh. Cyberlaw: Perlindungan Merek dalam Cyberspace. (Bandung: Refika Aditama. 2017), 81.

20 Okezone, "Ratusan Toko Online Ditutup Karena Bermasalah" diakses dari https://economy.okezone.com/read/2019/05/22/320/2058772/ratusan-toko-onlineditutup-karena-bermasalah?page $=1$ pada tanggal 23 Februari 2020

21 Muhammad Amirulloh. Loc.Cit. 
merek terkenal tersebut pada produk yang dijual oleh pedagang (merchant) yang sebenarnya tidak ada sangkut pautnya dengan merek terkenal. Meskipun dalam UU MIG tidak memberikan pelindungan khusus bagi merek terkenal (well-known mark) namun berdasarkan Pasal 21 ayat (1) huruf b dan c UU MIG memberikan pelindungan kepada merek terkenal dengan menolak permohonan pendaftaran merek apabila memiliki persamaan pada pokoknya atau keseluruhan dengan merek terkenal, yang dijelaskan dalam penjelasan Pasal 21 ayat (1) huruf b UU MIG bahwa alasan penolakan permohonan pendaftaran yaitu apabila memiliki persamaan pada pokoknya atau keseluruhan dengan merek terkenal milik pihak lain untuk barang atau jasa yang sejenis dengan memperhatikan pengetahuan umum masyarakat mengenai Merek tersebut di bidang yang bersangkutan.

Maka berdasarkan penjelasan tersebut meskipun suatu merek telah diketahui reputasinya oleh masyarakat luas sehingga merek tersebut tergolong merek terkenal atau well-known mark, walaupun ia belum terdaftar maka mendapat pelindungan ketika terdapat pihak yang dengan itikad tidak baik ingin mendaftarkan merek yang serupa dengan merek terkenal melalui cara melakukan penolakan atas permohonan merek tersebut saat pemeriksaan substantif. Namun, sebelum pemeriksaan substantif, yaitu pada tahap pengumuman pemilik merek terkenal dapat mengajukan keberatan apabila terdapat permohonan merek yang memiliki persamaan dengan merek terkenal.

Lebih lanjut, berdasarkan Pasal 76 UU No. 20 Tahun 2016 pemilik merek terkenal dapat mengajukan gugatan pembatalan merek yang telah terdaftar melalui Pengadilan Niaga dengan menunjukkan bukti-bukti bahwa ia merupakan pemilik merek terkenal dan memenuhi syarat-syarat merek terkenal seperti yang dikemukakan oleh WIPO Joint Recommendation Concerning Provisions on the Protection of Well-Known Marks ${ }^{22}$. Namun merek terkenal tersebut haruslah didaftarkan terlebih dahulu agar mendapat pelindungan yang komprehensif dikarenakan UU No. 20 Tahun 2016 menganut sistem konstitutif atau first-to-file principle yang berarti pelindungan didapat setelah pendaftaran bukan pemakaian.

Tetapi praktik passing off yang ditemukan dalam digital platform marketplace bukan pendaftaran merek yang merupakan hasil dari pendomplengan merek terkenal melainkan merupakan tindakan curang yang dilakukan oleh pedagang dengan menjual produk yang telah memiliki merek terdaftar tetapi merek tersebut belum dikenal masyarakat luas sehingga ia mencantumkan merek terkenal pada judul produk atau laman informasi dengan tujuan apabila masyarakat mencari produk dari merek terkenal maka produk dari merek yang belum terkenal tadi juga muncul sehingga membantu promosi produk tersebut tanpa mengeluarkan biaya untuk iklan

Lebih lanjut, untuk menentukan apakah suatu perbuatan tergolong praktik passing off atau bukan maka perbuatan tersebut perlu diidentifikasi apakah memenuhi syaratsyarat berikut ${ }^{23}$ :

1. Goodwill atau reputasi

2. Penggambaran yang palsu atau menyesatkan (Misrepresentation)

3. Kerugian (damages)

Dalam praktik passing off yang ditemukan dalam digital platform marketplace dapat diidentifikasi apakah memenuhi syarat-syarat tersebut. Pertama merek terkenal harus

22 Hukumonline, "Merek Terkenal yang Tidak Terdaftar" diakses dari https://www.hukumonline.com/klinik/detail/ulasan/cl5892/merek-terkenal-yang-tidakterdaftar pada 8 Februari 202015.54 WIB

23 Aurora Quintina. Op.cit. 17-19. 
memperhatikan mengenai reputasi yang ia miliki dengan membuktikan reputasinya dalam suatu wilayah dan adanya daya pembeda ${ }^{24}$. Kedua adanya penggambaran yang keliru dan menyesatkan yang dapat menimbulkan kebingungan masyarakat. Pada negara-negara common law tuntutan atas passing off yang terjadi pada pasar konvensional dapat dimintakan suatu penetapan hakim (injunction) yang berisi: 25

1. Penghentian perbuatan tergugat, dalam hal ini pedagang (merchant), yang menyesatkan dan pernyataan untuk tidak mengulangi perbuatan tersebut dengan pertama menarik dari peredaran barang atau jasa yang menyesatkan untuk diserahkan dan dihancurkan, dan/atau kedua meminta ganti rugi materiil atas kerugian nyata yang diderita dan sejumlah keuntungan yang seharusnya diperoleh milik terkenal.

2. Meminta ganti rugi yang bersifat immateril akibat kerugian terhadap reputasinya.

Sedangkan menurut UU No. 20 Tahun 2016, apabila terdapat pihak yang secara tanpa hak menggunakan merek yang mempunyai persamaan pada pokoknya atau keseluruhannya maka berdasarkan Pasal 83 ayat (1) pemilik merek terdaftar dapat mengajukan gugatan berupa gugatan ganti dan/atau penghentian semua perbuatan yang berkaitan dengan penggunaan merek tersebut. Selanjutnya, Pasal 83 ayat (2) memberikan pelindungan hukum pada merek terkenal yang belum terdaftar untuk dapat juga dapat mengajukan gugatan perdata. Dilanjutkan pada Pasal 83 ayat (3) pengajuan gugatan tersebut diajukan kepada Pengadilan Niaga. Walaupun dalam Pasal 83 UU No. 20 Tahun 2016 ini mengatur pengajuan gugatan yang diakibatkan perbuatan yang dilakukan dalam pasar konvensional, namun Pasal 25 UU ITE sebagai pasal yang menjembatani penggunaan kekayaan intelektual dalam ruang lingkup siber dengan memperhatikan peraturan perundang-undangan kekayaan intelektual terkait. Oleh karena itu, Pasal 83 UU No. 20 Tahun 2016 juga berlaku untuk pengajuan gugatan ganti rugi atas perbuatan yang dilakukan dalam perdagangan elektronik.

Selama masih dalam pemeriksaan sengketa, berdasarkan Pasal 84 ayat (1) UU No. 20 Tahun 2016 pemilik merek dan/atau penerima lisensi sebagai penggugat dapat mengajukan permohonan kepada hakim untuk menghentikan kegiatan produksi, peredaran, dan/atau perdagangan barang dan/atau jasa yang menggunakan merek tersebut secara tanpa hak. Hal ini dapat diajukan pemilik merek guna menjaga agar pemilik merek tidak terus merugi atas penggunaan merek tanpa hak tersebut. Tetapi untuk penyerahannya berdasarkan Pasal 84 ayat (2) UU No. 20 Tahun 2016, hakim dapat memerintahkan penyerahan barang atau nilai barang setelah putusan pengadilan mempunyai kekuatan hukum tetap.

Namun selain pengajuan gugatan kepada Pengadilan Niaga, berdasarkan Pasal 93 UU MIG para pihak dapat menyelesaikan sengketa melalui arbitrase atau alternatif penyelesaian sengketa, yang berdasarkan penjelasan pasal tersebut alternatif penyelesaian sengketa berupa negosiasi, mediasi, konsiliasi, dan cara lain yang dipilih oleh para pihak. Salah satu bentuk tindakan yang dapat dilakukan oleh pemilik terkenal melalui penyelesaian sengketa alternatif adalah dengan bentuk negosiasi antara pemilik merek terkenal dengan pedagang (merchant) dan penyedia platform marketplace. Negosiasi tersebut diakomodir oleh penyedia platform marketplace dengan menyediakan

24 Ibid.

25 Ibid.,20 
layanan pengaduan sebagai sarana bagi pemilik merek terkenal untuk melakukan pelaporan atas praktik pemboncengan reputasi yang dilakukan oleh pedagang.

Lebih lanjut, apabila merek terkenal tersebut telah terdaftar kemudian terdapat pihak, atau dalam hal ini, pedagang (merchant) mendompleng reputasi merek terkenal tersebut dengan mencantumkan pada produk yang ia jual yang sebenarnya tidak ada kaitannya dengan merek terkenal maka pemilik merek terkenal dapat mengenakan ketentuan pidana sebagai tindakan terakhir yang berdasarkan UU No 20 Tahun 2016 tepatnya Pasal 100 ayat (1) yang menyatakan bahwa apabila terdapat seorang yang dengan tanpa hak menggunakan Merek yang sama pada keseluruhannya dengan Merek terdaftar milik pihak lain untuk barang dan/atau jasa sejenis yang diproduksi dan/atau diperdagangkan, maka dapat dipidana penjara paling lama 5 (lima) tahun dan/atau denda paling banyak Rp. 2.000.000.000 (dua miliar rupiah). Selanjutnya Pasal 103 UU No. 20 Tahun 2016 menyatakan bahwa Pasal 100 hingga Pasal 102 merupakan delik aduan, sehingga untuk memproses praktik passing off terhadap merek terkenal dalam digital platform marketplace perlu ada pengaduan terlebih dahulu dari pihak korban, dalam hal ini, pemilik merek dapat mengajukan pengaduan dahulu untuk memproses gugatan.

Digital platform marketplace sebagai sistem elektronik yang bergerak di bidang perdagangan diamanahkan oleh Pasal 15 UU ITE untuk menyelenggarakan sistem elektronik secara andal dan aman serta bertanggung jawab terhadap pengoperasiannya. Maka baik pihak penyedia platform marketplace maupun pihak pedagang dan konsumen sama-sama memiliki tanggung jawab untuk menjaga platform yang digunakan.

Lebih lanjut, dalam digital platform marketplace pedagang (merchant) diberi keleluasaan dalam melakukan publikasi konten dan promosi terhadap barang yang ia dagangkan namun Pasal 9 UU ITE memberikan batasan yaitu bahwa pelaku usaha yang menawarkan produk dalam sistem elektronik harus menyediakan informasi yang lengkap dan benar berkaitan syarat kontrak, produsen, dan produk yang ditawarkan. Maka berdasarkan pasal tersebut pedagang (merchant) harus mencantumkan informasi yang jelas dan benar terkait produk yang dijual tanpa mendompleng suatu merek terkenal yang mengakibatkan misinformation dan kebingungan dalam masyarakat. Dimana hal tersebut dilarang oleh oleh Pasal 28 ayat (1) UU ITE yang menjelaskan bahwa sebuah perbuatan dilarang apabila seseorang menyebarkan berita bohong dan menyesatkan yang mengakibatkan kerugian konsumen dalam transaksi elektronik.

Lebih lanjut, sejalan dengan Pasal 9 UU ITE dalam Peraturan Pemerintah Nomor 71 Tahun 2019 tentang Penyelenggaraan Sistem dan Transaksi Elektronik (PP PSTE) sebagai peraturan pelaksana UU ITE, dalam Pasal 48 ayat (1) PP PSTE juga mengatur bahwa pelaku usaha yang menawarkan produk melalui sistem elektronik harus menyediakan informasi yang lengkap dan benar berkaitan dengan produk yang ditawarkan. Oleh karena itu, pedagang (merchant) telah ditegaskan untuk menampilkan informasi yang benar dalam membuat konten barang yang didagangkan.

Apabila terdapat pedagang yang menampilkan informasi tidak benar dengan mencantumkan merek terkenal yang mengakibatkan kerugian bagi pemilik terkenal dan konsumen, maka pemilik merek dapat mengajukan tindakan hukum sesuai dengan Pasal 39 UU ITE yaitu:

(1) Gugatan perdata dilakukan sesuai dengan ketentuan Peraturan Perundang-undangan.

(2) Selain penyelesaian gugatan perdata sebagaimana dimaksud pada ayat (1), para pihak dapat menyelesaikan sengketa melalui arbitrase, atau lembaga penyelesaian sengketa alternatif lainnya sesuai dengan ketentuan Peraturan Perundang-undangan. 
Namun selain gugatan perdata dan penyelesaian sengketa alternatif lainnya, praktik pendomplengan merek atau passing off yang dilaksanakan di sistem perdagangan elektronik yang berbentuk marketplace juga dapat dikenakan ketentuan pidana.

Hal ini dikarenakan praktik tersebut dapat dikatakan perbuatan yang mencantumkan informasi tidak benar dengan menggukan merek terkenal pada konten yang ia publikasikan dalam digital platform marketplace. Oleh karena itu pedagang (merchant) dapat dikenakan Pasal 45A ayat (1) UU ITE yang menyatakan bahwa setiap orang yang dengan sengaja dan tanpa hak menyebarkan berita bohong dan menyesatkan yang mengakibatkan kerugian konsumen dalam Transaksi Elektronik sebagaimana dimaksud Pasal 28 ayat (1) maka dapat dipidana dengan pidana penjara paling lama 6 (enam) tahun dan/atau denda paling banyak Rp 1.000.000.000,00 (satu miliar rupiah).

Namun sebelum mengajukan gugatan baik perdata maupun pidana maka pemilik merek dapat melakukan peringatan terlebih dahulu kepada pedagang (merchant) atau dapat melakukan pengaduan kepada pihak penyedia digital platform marketplace. Saat ini setiap penyedia digital platform marketplace telah menyediakan layanan pengaduan terkait pelanggaran kekayaan intelektual sehingga pemilik merek dapat melakukan pengaduan kepada digital platform marketplace untuk meminta tindakan berupa penghapusan konten atau penutupan toko.

Penyedia platform memberikan keleluasaan kepada pedagang untuk berhubungan langsung kepada konsumen dalam transaksi jual-beli. Hal ini menyebabkan pedagang dapat melakukan praktik-praktik yang tidak beritikad baik untuk menarik konsumen dan mendapatkan keuntungan, sehingga mengakibatkan penyedia platform juga terdampak kerugian atas praktik yang dilakukan oleh pedagang. Baik UU ITE maupun PP PSTE belum mengatur secara implisit mengenai pembagian kewajiban dan tanggung jawab.

Oleh karena itu Kementerian Komunikasi dan Informatika mengeluarkan kebijakan yaitu Surat Edaran (Kominfo) No. 5 Tahun 2016 yang mengatur batasan tanggung jawab penyedia platform dan pedagang dalam platform marketplace termasuk di dalamnya melarang konten bermuatan melanggar kekayaan intelektual dan merupakan kewajiban penyedia digital platform marketplace untuk melakukan tindakan terhadap aduan atau pelaporan atas konten yang melanggar dengan cara nelakukan pemeriksaan, melakukan tindakan penghapusan dan/atau pemblokiran konten, memberikan notifikasi ke pedagang (merchant) bahwa kontennya melanggar. Kemudian jangka waktu penghapusan dan/atau pemblokiran terhadap konten yang melanggar kekayaan intelektual selambat-lambatnya adalah 14 (empat belas) hari kalender sejak menerima pengaduan.

Berdasarkan pendapat Bayu Dwi Anggono meskipun surat edaran bukan tergolong peraturan perundang-undangan (regeling) dan juga keputusan tata usaha negara (beschikking). Surat edaran tergolong kebijakan (beleidsregel) atau peraturan perundang-undangan semu ( $p$ seudo wetgeving) yang merupakan produk hukum yang isinya secara materil mengikat umum namun tidak termasuk peraturan perundangundangan karena ketiadaan wewenang pembentuknya untuk membentuknya sebagai peraturan perundang-undangan ${ }^{26}$. Dengan lahirnya surat edaran tersebut untuk

26 Hukumonline "Surat Edaran Kerikil Dalam Perundang-undangan" diakses dari https://www.hukumonline.com/berita/baca/lt54b1f62361f81/surat-edaran-kerikil-dalamperundang-undangan/ pada 25 Februari 2020 
memberikan pelindungan hukum bagi penyedia platform dan pedagang (merchant) serta pengguna platform dengan memastikan batasan tanggung jawab dan kewajiban yang jelas antara para pihak dalam melangsungkan transaksi.

\subsection{Penegakan Hukum dan Tindakan Hukum yang dapat Dilakukan Pemilik Merek Terkenal Terkait Adanya Praktik Passing Off dalam Digital Platform Marketplace di Indonesia}

Penegakan hukum merupakan tahap selanjutnya setelah pembuatan hukum dengan pelaksanaan secara konkrit dalam kehidupan masyarakat sehari-hari ${ }^{27}$. Penegakan hukum terhadap praktik passing off dalam digital platform marketplace telah diatur dalam beberapa peraturan baik peraturan dari aspek hukum merek maupun dari aspek hukum siber. Selain itu pemilik merek terkenal yang memiliki hak ekslusif atas mereknya juga diberi wewenang oleh undang-undang untuk melakukan tindakantindakan hukum untuk melindungi mereknya dari perbuatan-perbuatan pedagang yang beritikad tidak baik.

Tindakan yang dapat dilakukan oleh pemilik merek terkenal terhadap praktik pemboncengan reputasi atas mereknya dalam marketplace terdapat beberapa peraturan seperti dalam Pasal 83 UU MIG yang berbunyi:

(1) Pemilik Merek terdaftar dan/atau penerima Lisensi Merek terdaftar dapat mengajukan gugatan terhadap pihak lain yang secara tanpa hak menggunakan Merek yang mempunyai persamaan pada pokoknya atau keseluruhannya untuk barang dan/atau jasa yang sejenis berupa:

a. gugatan ganti dan/atau

b. penghentian semua perbuatan yang berkaitan dengan penggunaan Merek tersebut.

(2) Gugatan sebagaimana dimaksud pada ayat (1) dapat pula diajukan oleh pemilik Merek terkenal berdasarkan putusan pengadilan.

(3) Gugatan sebagaimana dimaksud pada ayat (1) diajukan kepada Pengadilan Niaga

Lebih lanjut, selama kasus masih dalam pemeriksaan pemilik merek juga dapat mengajukan permohonan seperti yang dinyatakan oleh Pasal 84 UU MIG yang berbunyi:

(1) Selama masih dalam pemeriksaan dan untuk mencegah kerugian yang lebih besar, pemilik Merek dan/atau penerima Lisensi selaku penggugat dapat mengajukan permohonan kepada hakim untuk menghentikan kegiatan produksi, peredaran, dan/atau perdagangan barang dan/atau jasa yang menggunakan Merek tersebut secara tanpa hak.

(2) Dalam hal tergugat dituntut menyerahkan barang yang menggunakan Merek secara tanpa hak, hakim dapat memerintahkan penyerahan barang atau nilai barang tersebut dilaksanakan setelah putusan pengadilan mempunyai kekuatan hukum tetap.

Selain gugatan perdata, pemilik merek dapat melakukan tindakan melalui ketentuan pidana sebagai sarana terakhir atau ultimatum remedium (ultima ratio principle) apabila sarana-sarana lain tidak cukup memuaskan dalam penanggulangan pelanggaran merek ${ }^{28}$ yang tertera pada Pasal 100 ayat (1) UU MIG yang berbunyi:

(1) Setiap Orang yang dengan tanpa hak menggunakan Merek yang sama pada keseluruhannya dengan Merek terdaftar milik pihak lain untuk barang dan/atau jasa sejenis yang diproduksi dan/atau diperdagangkan, dipidana dengan pidana penjara paling

27 Rahardjo, Satjipto. Ilmu Hukum. (Bandung: Citra Aditya Bakti. 2014), Hlm 191

28 Budhijanto, Danrivanto. Cyber Law dan Revolusi Industri 4.0. (Bandung: Logoz. 2019), 47. 
lama 5 (lima) tahun dan/atau pidana denda paling banyak Rp2.000.000.000,00 (dua miliar rupiah).

Diakibatkan praktik pelanggaran merek dilakukan dalam cyberspace maka penegakannya juga memperhatikan UU ITE sebagai undang-undang dalam aspek hukum siber, tindakan yang dapat dilakukan pemilik merek yaitu mengajukan gugatan perdata atau menyelesaikan sengketa melalui arbitrase atau lembaga penyelesaian sengketa alternatif lainnya sesuai dengan Pasal 39 UU ITE. Namun pemilik merek juga menempuh jalur pidana untuk menyelesaikan sengketa sesuai dengan Pasal 45A ayat (1) UU ITE yang berbunyi:

(1) Setiap Orang yang dengan sengaja dan tanpa hak menyebarkan berita bohong dan menyesatkan yang mengakibatkan kerugian konsumen dalam Transaksi Elektronik sebagaimana dimaksud dalam Pasal 28 ayat (1) dipidana dengan pidana penjara paling lama 6 (enam) tahun dan/atau denda paling banyak Rp1.000.000.000,00 (satu miliar rupiah).

Selain peraturan perundang-undangan, terdapat kebijakan yang dikeluarkan oleh Kominfo yaitu Surat Edaran Kominfo No. 5 Tahun 2016 yang memberikan hak kepada pemilik merek untuk melakukan tindakan atas praktik pemboncengan reputasi yang dilakukan dalam marketplace tertentu dengan mengajukan pengaduan kepada penyedia platform untuk menghapus atau memblokir konten yang melanggar kekayaan intelektualnya, hal ini tertera pada bagian "C. Kewajiban Penyedia Platform UGC meliputi: b. menyediakan saran pelaporan yang dapat digunakan untuk menyampaikan aduan mengenai konten yang dilarang di Platform UGC; c. melakukan tindakan terhadap aduan atau pelaporan atas konten; d. memperhatikan jangka waktu penghapusan dan/atau pemblokiran terhadap konten yang dilarang, yakni konten yang melanggar kekayaan intelektual selambat-lambatnya 14 (empat belas) hari kalender sejak pengaduan diterima oleh platform UGC"29.

Lebih lanjut, berdasarkan surat edaran tersebut, pemilik merek juga dapat meminta pertanggung jawaban dari pedagang (merchant) sebagai pihak yang melakukan pengunggahan konten yang melanggar kekayaan intelektual. Namun surat edaran tersebut diharapkan dibentuk menjadi peraturan (regeling) seperti Peraturan Menteri agar memiliki kekuatan hukum yang lebih kuat.

Meskipun telah terdapat beberapa peraturan yang secara penafsiran telah mengatur mengenai praktik passing off dalam digital platform marketplace. Namun pengaturan mengenai pelindungan terhadap passing off terhadap merek terkenal (wellknown mark) belum diatur secara pasti dan menyeluruh dalam UU MIG.

Jika dibandingkan dengan negara-negara common law, seperti Canada didalam UU Merek Canada (Trademark Act) perbuatan pemboncengan reputasi termasuk perbuatan yang tidak jujur dan tergolong perbuatan melawan hukum, khususnya dalam subseksi 7 (b) menyatakan bahwa: ${ }^{30}$

29 Surat Edaran Kementerian Komunikasi dan Informatika Nomor 5 Tahun 2016 tentang Batasan dan Tanggung Jawab Penyedia Platform dan Pedagang (Merchant) Perdagangan Melalui Sistem Elektronic (Electronic Commerce) Yang Berbentuk User Generated Content.

30 Canada Trademarks Act. Diakses melalui https://laws-lois.justice.gc.ca/eng/acts/t13/page-2.html\#h-450214 pada 28 Februari 2020 23:41 WIB 
"No person shall direct public attention to his goods, services or business in such a way as to cause or be likely to cause confusion in Canada, at the time he commenced so to direct attention to them, between his goods, services or business and the goods, services or business of another"

Selain Canada, di Amerika Serikat dalam Pasal 43(a) Lanham Act 1946 yang merupakan hukum federal mengenai persaingan curang yang memberi pelindungan merek dari pemboncengan reputasi. Selanjutnya di Australia terdapat Pasal 52 Trade Practices Act 1974 menjadi dasar upaya pelindungan merek dari praktik passing off atau pemboncengan reputasi. Pada negara-negara common law, gugatan passing off merupakan gugatan perdata sehingga yang dapat dituntut adalah ganti rugi, selain itu yang dapat diajukan dalam tuntutan berdasar passing off adalah suatu penetapan hakim (injunction) yang berisi: ${ }^{31}$

1. Penghentian perbuatan yang menyesatkan yang dilakukan oleh tergugat dan pernyataan untuk tidak mengulangi lagi

a. Menarik barang atau jasa yang menyesatkan dari peredaran untuk diserahkan atau dihancurkan

b. Meminta ganti rugi materiil atas kerugian nyata yang diderita dan sejumlah keuntungan yang seharusnya diperoleh, termasuk biaya pengacara dan biaya perkara

2. Meminta ganti rugi yang bersifat immateril akibat kerugian terhadap reputasinya

Oleh karena itu, UU MIG diharapkan juga melindungi merek dari pemboncengan reputasi mengingat reputasi merek, terutama merek terkenal, merupakan hasil dari kerja keras pemilik merek untuk membangun identitas produknya agar diketahui masyarakat luas. Selain itu, dengan perkembangan teknologi yang sangat pesat UU MIG saat ini belum mengatur mengenai pelindungan merek ataupun indikasi geografis dalam lingkup cyberspace. Sesuai dengan pemikiran Danrivanto Budhijanto dalam buku "Hukum Telekomunikasi, Penyiaran \& Teknologi Informasi" mengenai pengaturan di Indonesia atas kegiatan-kegiatan di cyberspace yaitu ${ }^{32}$ :

1. Perlunya kepastian hukum bagi para pelaku kegiatan-kegiatan di cyberspace;

2. Upaya untuk mengantisipasi implikasi-implikasi yang ditimbulkan akibat pemanfaatan teknologi informasi; dan

3. Adanya variable global yaitu perdagangan bebas dan pasar terbuka (WTO/GATT)

Berdasarkan pemikiran tersebut maka perlulah UU MIG mengatur secara spesifik mengenai kegiatan penggunaan merek dalam cyberspace mengingat keterkaitan kekayaan intelektual, salah satunya merek, dengan sistem informasi sangat erat hubungannya dan dalam rangka melindungi pemilik merek dan juga konsumen dari transaksi perdagangan bebas termasuk dalam transaksi digital platform marketplace. Selain pengaturan penggunaan merek dalam cyberspace, guna melindungi persamaan merek dalam pendaftaran dan menghindari banyaknya passing off, Dirjen KI sebagai pihak yang melakukan penerimaan permohonan merek diharapkan juga lebih melakukan pemeriksaan substansi merek lebih menyeluruh agar mengurangi terdaftarnya merek yang memiliki persamaan dengan merek terkenal, salah satu

31 Quintina, Aurora. Op.cit. 20.

32 Budhijanto, Danrivanto. Hukum Telekomunikasi, Penyiaran E Teknologi Informasi. Op.cit., 132. 
alternatifnya yaitu dengan menggunakan pemeriksaan secara online dengan suatu sistem teknologi guna menghindari human error.

Meskipun telah terdapat UU ITE yang berperan sebagai peraturan khusus yang mengatur kegiatan dalam transaksi elektronik, tetapi UU MIG sebagai peraturan khusus yang mengatur merek perlulah didalamnya juga mengatur pelindungan merek dalam kegiatan perdagangan elektronik. Hal ini merupakan bukti perwujudan asas Droit de Suit dalam hukum benda sehingga suatu merek tetap memperoleh pelindungan meskipun penggunaanya dalam sistem elektronik ${ }^{33}$ atau dalam hal ini dalam marketplace.

Dikarenakan saat ini belum ada pengaturan merek dalam kegiatan elektronik maka kegiatan dalam sistem elektronik mengacu pada UU ITE yang diatur lebih lanjut dalam PP PSTE. Pada Pasal 3 ayat (1) PP PSTE mengatur bahwa penyelenggara sistem elektronik harus menyelenggarakan sistemnya secara andal dan aman serta bertanggung jawab terhadap pengoperasiannya, yang dalam rangka menyelenggarakan dengan aman disebutkan dalam Pasal 5 ayat (1) PP PSTE yaitu penyelenggara sistem elektronik wajib memastikan sistemnya tidak memuat informasi elektronik dan/atau dokumen elektronik yang dilarang sesuai dengan ketentuan peraturan perundangundangan.

Pemilik merek dalam rangka melindungi mereknya dapat mengajukan aduan kepada Menteri Komunikasi dan Informatika apabila pemilik merek menemukan adanya pelanggaran kekayaan intelektual dalam konten yang dimuat penyelenggara sistem elektronik, dalam hal ini marketplace, sehingga bertentangan dengan Pasal 5 ayat (1) PP PSTE yang dalam Pasal 100 ayat (1) PP PSTE menyebutkan bahwa pelanggaran terhadap pasal tersebut dapat dikenakan sanksi administratif. Berdasarkan economic stimulus growth theory merek merupakan aset perusahaan dalam melakukan kegiatan usaha dan tindakan yang dilakukan oleh pemilik merek tersebut merupakan bentuk melindungi merek sebagai kekayaan intelektual yang dapat menumbuhkan perkembangan ekonomi sehingga melakukan tindakan atas pemboncengan reputasi merek terkenal agar menghilangkan hambatan perkembangan ekonomi ${ }^{34}$.

Kasus serupa mengenai gugatan yang dilayangkan pemilik terkenal terkait pelanggaran merek terhadap digital platform marketplace terjadi di Belgia yaitu kasus Lancôme melawan e-Bay dimana Lancôme sebagai penggugat berusaha mencegah e-bay untuk menampilkan produk-produknya yang dianggap melanggar oleh penggugat termasuk iklan produk yang ditampilkan sebagai imitasi, salinan, dan reproduksi atau berbau seperti produk Lancôme 35 .

Namun dalam kasus ini, Pengadilan Niaga Brussels menyatakan bahwa e-Bay tidak bertanggung jawab karena tidak memiliki pengetahuan aktual mengenai informasi illegal yang dihostingnya, atau tidak mengetahui fakta atau keadaan yang menunjukkan sifat illegal dan setelah mengetahui keadaan tersebut, e-Bay segera bertindak menghapus informasi tersebut atau memblokir aksesnya. Oleh karena itu, $e$ Bay terlindungi dibawah Pasal 12 hingga Pasal 15 E-Commerce Directive ${ }^{36}$. E-Commerce

33 Amirulloh, Muhammad. Op.cit., 123.

34 Ibid., 81-83.

35 ASY, Cheung dan KH, Pun. Comparative study on the liability for trade mark infringement of online auction providers. (Hong Kong: Sweet \& Maxwell Ltd. 2009). Hlm 9 diakses melalui http:/ /hub.hku.hk/handle/10722/129252

36 WIPO. Standing Committee on the Law of Trademarks, Industrial Designs and Geographical Indications. Geneva. (2010): 4-5. 
Directive ini merupakan kerangka hukum bagi perdagangan elektronik yang bertujuan sebagai petunjuk untuk menghilangkan hambatan untuk layanan perdagangan lintas batas di negara Uni Eropa serta memberi kepastian hukum kepada pelaku usaha dan masyarakat ${ }^{37}$.

Pada kasus ini E-Bay mengklaim bahwa kegiatannya hanya mentransmisikan informasi, yang sesuai dengan Pasal 12 E-Commerce Directive, dimana ia merupakan "the automatic, intermediate and temporary storage of that information", yang sesuai dengan Pasal 13 E-Commerce Directive. Selanjutnya berdasakan Pasal 14 E-Commerce Directive kegiatan hosting yang merupakan kegiatan menyimpan informasi yang disediakan oleh penerima layanan dibebaskan dari tanggung jawab, dan lebih utama berdasarkan Pasal 15 menyatakan bahwa tidak ada kwajiban umum untuk memantau informasi yang dihosting $e-B a y^{38}$.

Pemilik merek dalam melindungi mereknya dari pemboncengan reputasi dalam marketplace juga dapat melakukan tindakan hukum berupa negosiasi dengan langsung melakukan pengaduan kepada masing-masing pihak penyedia platform marketplace. Pada situs Bukalapak.com, pemilik merek terkenal dapat mengajukan laporan pelanggaran barang yang melakukan pemboncengan reputasi dengan melalui layanan "BukaBantuan" atau dengan melaporkan barang langsung pada halaman detail barang yang melanggar ${ }^{39}$. Dokumen yang diperlukan dalam melaporkan pelanggaran kekayaan intelektual dalam bukalapak.com yaitu:40

1. Sertifikat Hak Kekayaan Intelektual (Hak Merek/Hak Cipta/Hak Paten/ Hak Desain Industri/Hak Tata Letak Sirkuit Terpadu).

2. Identitas Pemohon.

3. Informasi dan alamat Pemilik Hak Kekayaan Intelektual.

4. Surat Kuasa (jika dikuasakan oleh prinsipal).

5. Surat Keberatan (Surat Permohonan Penghapusan Produk yang Melanggar Hak Kekayaan Intelektual).

6. URL/link produk yang melanggar Hak Kekayaan Intelektual.

Kemudian pada Tokopedia.com, pemilik merek dapat mengajukan laporan penjualan barang atau jasa yang membonceng reputasi merek terkenal dengan mengisi formulir daring yang memuat:41

1. Identitas Pelapor

2. Surat Kuasa Pelapor

3. Melengkapi formulir

4. Nama Produk

5. Link Produk

37 European Union "E-Commerce Directive" diakses melalui https://ec.europa.eu/digitalsingle-market/en/e-commerce-directive pada tanggal 3 Maret 2020 22:30 WIB

38 ASY, Cheung dan KH, Pun. Op.cit. 9.

39 Bukalapak "Cara Lapor Pelanggaran Barang" diakses melalui https://www.bukalapak.com/faq/pelanggaran/pelanggaran-produk/cara-laporpelanggaran-barang pada tanggal 3 Maret 2020 23:12 WIB

40 Bukalapak "Dokumen Pelanggaran Hak Kekayaan Intelektual" diakses melalui https://www.bukalapak.com/bantuan/pelanggaran/pelanggaran-hak-kekayaanintelektual/dokumen-laporan-pelanggaran-haki pada tanggal 3 Maret 2020 23:14 WIB

41 Tokopedia "Pelaporan Pelanggaran Konten Produk di Tokopedia" diakses melalui https://www.tokopedia.com/help/article/a-1697 pada tanggal 3 Maret 2020 23:23 WIB 
6. Sertifikat Merek yang sudah terdaftar dan masih berlaku di wilayah Republik Indonesia

Hal yang serupa pada platform marketplace Shopee.com, pemilik merek terkenal dapat mengisi formulir pelanggaran kekayaan intelektual apabila menemukan produk yang membonceng reputasi merek terkenal dengan melengkapi dokumen berikut: ${ }^{42}$

1. Surat Kuasa (jika pelapor bukan pemilik Kekayaan Intelektual)

2. Sertifikat Pendaftaran Merek Dagang Lokal

3. Panduan Bergambar/ Daftar Harga

Meskipun setiap digital platform marketplace telah memiliki layanan pengaduan pelanggaran kekayaan intelektual, namun dalam menjaga sistemnya selalu aman setiap marketplace seharusnya memiliki program yang dapat mendeteksi pelanggaran merek tanpa perlu pengaduan atau adanya program filtering konten-konten dalam sistemnya guna menghindari tuntutan dari pemilik merek serta memberikan kenyamanan bagi konsumen.

\section{Kesimpulan}

Pemilik merek terkenal memiliki pelindungan hukum atas praktik passing off yang dilakukan di dalam digital platform marketplace terhadap mereknya karena berdasarkan Pasal 83 ayat (1) dan ayat (2) Undang-Undang Nomor 20 Tahun 2016 tentang Merek dan Indikasi Geografis dan berdasarkan Pasal 25, Pasal 9, dan Pasal 28 ayat (1) UndangUndang Nomor 19 Tahun 2016 tentang Perubahan Atas Undang-Undang Nomor 11 Tahun 2008 tentang Informasi dan Transaksi Elektronik. Oleh karena itu, pemilik merek dapat melakukan tindakan-tindakan terhadap pedagang (merchant) ataupun penyedia platform marketplace dan untuk mendapat pelindungan lebih komprehensif pemilik merek terkenal haruslah mendaftarkan mereknya terlebih dahulu. Tindakan hukum yang tepat bagi pemilik merek terkenal untuk melindungi mereknya dari praktik passing off atau pemboncengan reputasi dalam digital platform marketplace adalah mengajukan gugatan perdata dengan memohon ganti rugi baik materil maupun immateril diikuti dengan menghapus konten yang melanggar dengan membuktikan adanya reputasi, adanya penggambaran yang menyesatkan, dan menyebabkan kerugian. Apabila pemilik merek merasa belum cukup puas atas gugatan perdata dalam menanggulangi praktik passing off maka dapat melalui ketentuan pidana dengan mengajukan gugatan kepada Pengadilan Niaga. Namun sebelum mengajukan gugatan, pemilik merek dapat melakukan pengaduan kepada masing-masing digital platform marketplace.

\section{DAFTAR PUSTAKA \\ Buku:}

Amirulloh, Muhammad. Cyberlaw: Perlindungan Merek dalam Cyberspace. Bandung: Refika Aditama. 2017

Budhijanto, Danrivanto. Cyber Law dan Revolusi Industri 4.0. Bandung: Logoz. 2019

42 Shopee "Bagaimana Saya Bisa Melaporkan Pelanggaran Hak-Hak Saya" diakses melalui https:// help.shopee.co.id/s/article/Bagaimana-saya-bisa-melaporkan-pelanggaran-hakhak-saya pada tanggal 3 Maret 2020 23:47 WIB 
Budhijanto, Danrivanto. Hukum Telekomunikasi, Penyiaran $\mathcal{E}$ Teknologi Informasi. Bandung: Refika Aditama. 2010

Harahap, Yahya. Tinjauan Merek Secara Umum Dan Hukum Merek Di Indonesia Berdasarkan Undang-Undang No 19 Tahun 1992, Jakarta: Citra Aditya Bakti

Jened, Rahmi. Hukum Merek dalam Era Globalisasi \& Integrasi Ekonomi. Jakarta: Kencana, 2015.

Lindsey, Tim (et.al.). Hak Kekayaan Intelektual. Bandung: Alumni. 2013

Ramli Ahmad M. Cyber Law dan Haki, Bandung: Refika Aditama, 2018

Ramli, Ahmad M. Hak Cipta, Disrupsi Digital Ekonomi Kreatif, Bandung: Alumni, 2018.

Rahardjo, Satjipto. Ilmu Hukum. Bandung: Citra Aditya Bakti. 2014

\section{Jurnal:}

ASY, Cheung dan KH, Pun. "Comparative study on the liability for trade mark infringement of online auction providers." Hong Kong: Sweet \& Maxwell Ltd. (2009).

Alfons, Maria, "Implementasi Hak Kekayaan Intelektual dalam Perspektif Negara Hukum", Jurnal Legislasi Indonesia, Volume 14, Nomor 3, (September 2017)

Ahyani, Sri. "Perlindungan Hukum Terhadap Merek atas Action for Passing Off". Jurnal Wawasan Hukum, Vol 27 No, 02, (2012)

Marco, Robert dan Ningrum, Bernadheta Tyas Puspa. “Analisis Sistem Informasi Emarketplace Pada Usaha Kecil Menengah (UKM) Kerajinan Bambu Dusun Brajan”, Jurnal Ilmiah DASI, Volume 18. Nomor 2, (Juli 2017)

Quintina, Aurora, et.al. "Pemboncengan Reputasi (Passing Off) Terhadap Pemilik Merek Terdaftar Di Indonesia Ditinjau Dari Segi Perlindungan Hukum." Jurnal Mercatoria. Volume 2 Nomor 1. (2009)

Setyawati, Desy Ary dan M, Dahlan dan Rasyid, Nur. "Perlindungan Bagi Hak Konsumen dan Tanggung Jawab Pelaku Usaha Dalam Perjanjian Transaksi Elektronik." Syiah Kuala Law Journal. Volume 1 Nomor 3. (Desember 2017)

Sunny, Dio Shafreeza. "Tanggung Gugat Produsen Pemilik Produk Yang Melakukan Pemboncengan Reputasi", Skripsi Universitas Airlangga, Surabaya, (2015)

Sanjoto, Liany Dewi. "Perlindungan Hukum Bagi Konsumen Pemakai Jasa Elektronik dalam Transaksi Melalui Marketplace." Jurnal Ilmiah Dunia Hukum. Volume 3 Nomor 2. (April 2019)

WIPO. "Standing Committee on the Law of Trademarks, Industrial Designs and Geographical Indications." Geneva. (2010)

\section{Kamus/ Ensiklopedia:}

Garner, Bryan A. Black's Law Dictionary 9th Edition. Minnesota: West Publishing Co. 2009.

\section{Dokumen/ Instrumen Hukum Nasional dan Internasional:}

Canada Trademarks Act.

Indonesia. Undang-Undang Nomor 20 tahun 2016 tentang Merek dan Indikasi Geografis (Lembaran Negara Republik Indonesia Tahun 2016 Nomor 252, Tambahan Lembaran Negara Republik Indonesia Nomor 5953)

Indonesia. Undang-Undang Nomor 19 Tahun 2016 tentang Perubahan Atas UndangUndang No. 11 tahun 2008 tentang Informasi dan Transaksi Elektronik (Lembaran Negara Republik Indonesia Tahun 2016 Nomor 251, Tambahan Lembaran Negara Republik Indonesia Nomor 5952) 
Indonesia. Surat Edaran Kementerian Komunikasi dan Informatika Nomor 5 Tahun 2016 tentang Batasan dan Tanggung Jawab Penyedia Platform dan Pedagang (Merchant) Perdagangan Melalui Sistem Elektronic (Electronic Commerce) Yang Berbentuk User Generated Content.

\section{Website}

Setiawati, Lucky, Perlindungan Merek Terkenal yang Tidak Terdaftar di Indonesia. https://www.hukumonline.com/klinik/detail/ulasan/cl5892/merekterkenal-yang-tidak-terdaftar diakses pada 8 Februari 2020

European Union,"E-Commerce Directive"https://ec.europa.eu/digital-singlemarket/en/e-commerce-directive Diakses pada tanggal 3 Maret 2020

Bukalapak.com

Tokopedia.com

Shopee.com 